\title{
Voltammetric Determination of Cadmium, Copper and Lead Using Glassy carbon Electrode
}

\author{
M. Khodari ${ }^{1}$, Ekram M. Rabie ${ }^{1}$, Fathy M. Mohamed ${ }^{2}$, E man A. Hassan ${ }^{2 *}$ \\ ${ }^{I}$ Chemistry department, Faculty of Science, South Valley University \\ ${ }^{2}$ Qena Company for Water and Waste Water, Holding company of water and waste water
}

\begin{abstract}
Cyclic voltammetry and linear sweep voltammetry were used to determine cadmium, copper and lead metal ions using glassy carbon electrode. From cyclic measurements, cadmium, copper and lead showed a well single anodic peak at $-547,+191.5$ and $-520 \mathrm{mV}$ respectively. Several parameters affecting the stripping current response were investigated and optimized. Under optimal conditions, the glassy carbon electrode showed a good linear response to $\mathrm{Pb}^{2+}, \mathrm{Cd}^{2+}$ and $\mathrm{Cu}^{2+}$ in the concentration range from $8 \times 10^{-6} \mathrm{M}$ to $1 \times 10^{-4} \mathrm{M}$. The detection limits were $2 \times 10^{-7} \mathrm{M}$ for $\mathrm{Pb}^{2+}, 9 \times 10^{-7} \mathrm{M}$ for $\mathrm{Cd}^{2+}$ and $1 \times 10^{-7} \mathrm{M}$ for $\mathrm{Cu}^{2+}$ calculated for a single-tonoise ratio of $3(\mathrm{~S} / \mathrm{N}=3)$. The proposed method was successfully applied for determining $\mathrm{Pb}^{2+}, \mathrm{Cd}^{2+}$ and $\mathrm{Cu}^{2+}$ contents in well water samples.
\end{abstract}

\section{Introduction}

Voltammetry refers to a class of electrochemical techniques in which the current at the working electrode is measured as a function of potential waveform applied to the electrode. The potential of this electrode serves as the driving force for the reaction; i.e. it is controlled parameter that causes the chemical species present in the solution to be electrolyzed (reduced or oxidized) at the surface. The reducing or oxidizing strength of the electrode is controlled by the applied potential ${ }^{[1] .}$

Heavy metals refer to the heavy metals and their respective compounds arising from external contamination, and are absorbed and accumulated in CMM. Arsenic (As), cadmium (Cd), lead (Pb) and mercury $(\mathrm{Hg})$ are those heavy metals with relatively high toxicity to human beings. Heavy-metal ions are ubiquitous in nature, thus resulting in a serious environmental problem. Due to their high toxicity, ${ }^{[2]}$.

Copper and cadmium, are two important elements in the environment and they have essential roles in many different biological systems ${ }^{[3]}$. Copper is an essential trace element in biological systems ${ }^{[4]}$ and living organisms; it serves as a cofactor in at least 30 important enzymes ${ }^{[5]}$. Copper also causes the ischaemic heart disease, anaemia, bone disorders ${ }^{[6]}$.

Cadmium is a cumulative toxic metal whose presence in the environment has increasing concerning.The main organs for cadmium accumulation in humans are kidney, liver, lung and pancreas. Cadmium toxicity may be manifested by a variety of syndromes and effects including renal dysfunction, hypertension, hepatic injury, lung damage and teratogenic effects ${ }^{[7]}$.

Cadmium and lead are of public health interest because of several dangerous effects that they may cause to humans. They are widely dispersed in the environment, and exposure to either elements can increase the number of adverse health effects due to their toxicity after accumulation in multiple organs in the human body ${ }^{[8]}$.

The present work is aimed to study and determine cadmium, copper and lead metal ions electrochemically using glassy carbon electrode. Also it aimed to optimize the most suitable conditions to determine these metal ions in different well water samples.

\subsection{Cyclic voltammetric Measurements:}

\section{Results and discussion}

From cyclic measurements, cadmium, copper and lead showed a well single anodic peak at -547 , +191.5 and $-520 \mathrm{mV}$ respectively. These peaks arise from the reoxidation of the metal. Fig. ( 1 )shows repetitive cyclic voltammograms for $8 \times 10^{-5} \mathrm{~mol} \mathrm{dm}^{-3}$ of cadmium in $0.1 \mathrm{M}$ acetate buffer $(\mathrm{pH}=5)$ using $50 \mathrm{mV} / \mathrm{s}$ scan rate. This figure indicates that the oxidation peak current decreases more in the second and third cycles but Ep was not be affected .
$\mathrm{M}^{++}+2 \mathrm{e}^{-} \rightarrow \mathrm{M}$
Preconcentration step
$\mathrm{M} \rightarrow \mathrm{M}^{++}+2 \mathrm{e}^{-}$
Stripping step 


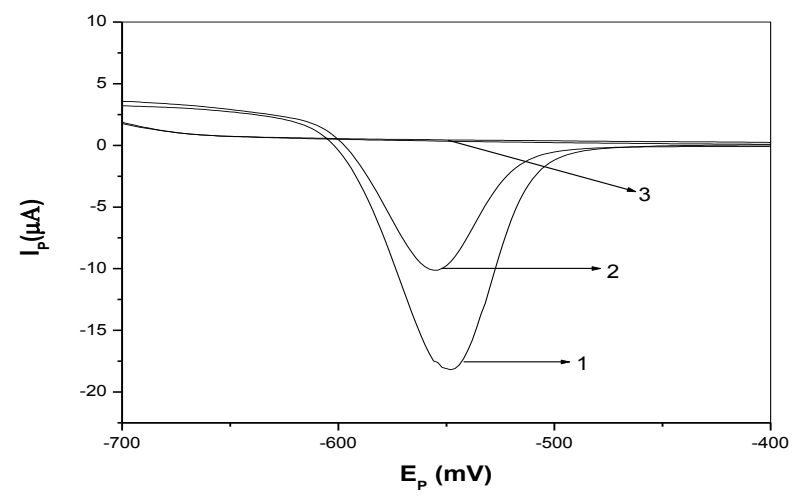

Fig(1):Repetitive cyclic voltammogrames for $8 \times 10^{-5} \mathrm{~mol}^{-1}$ cadmium $\left(\mathrm{Cd}^{++}\right)$in $0.1 \mathrm{M}$ acetate buffer (pH 5), deposition time $75 \mathrm{~s}$ and scan rate $50 \mathrm{mVs}^{-1}$ using glassy carbon electrode.

The resulting anodic peak current response was examined with respect to each of the following; supporting electrolyte and its strength, $\mathrm{pH}$, scan rate, and other variables. The collected results are shown in Table 1.

Table 1. Effect of different parameters on the peak response of $\mathrm{Cd}^{++}, \mathrm{Pb}^{++}$and $\mathrm{Cu}^{++}$.

\begin{tabular}{|c|c|c|c|c|c|c|c|}
\hline Metal & $\begin{array}{l}\text { supporting } \\
\text { electrolyte }\end{array}$ & $\begin{array}{l}\text { Strength of } \\
\text { supporting } \\
\text { electrolyte }\end{array}$ & $\mathrm{pH}$ & Scan rate & $\begin{array}{c}\text { Deposition } \\
\text { Potential }\end{array}$ & $\begin{array}{c}\text { Deposition } \\
\text { Time }\end{array}$ & Detection Limit \\
\hline $\mathrm{Cd}^{++}$ & $\begin{array}{c}\text { Britton-Robinsion } \\
\text { buffer }\end{array}$ & $0.1 \mathrm{M}$ & 2 & 50 & 0.0 & 90 & $1 \times 10^{-7} \mathrm{~mol} \mathrm{dm}^{-3}$ \\
\hline $\mathrm{Pb}^{++}$ & Acetate buffer & $0.5 \mathrm{M}$ & 5 & 50 & 0.0 & 50 & $2 \times 10^{-7} \mathrm{~mol} \mathrm{dm}^{-3}$ \\
\hline $\mathrm{Cu}^{++}$ & Acetate buffer & $0.1 \mathrm{M}$ & 5 & 50 & 0.0 & 75 & $9 \times 10^{-7} \mathrm{~mol} \mathrm{dm}^{-3}$ \\
\hline
\end{tabular}

\subsection{Influence of The Supporting Electrolyte and Its Ionic Strength :}

The influence of the supporting electrolyte on the peak current of the oxidation of cadmium,copper and lead was tested using different electrolytes. These electrolytes include sodium chloride, Disodium hydrogen phosphate, sodium nitrate, Acetate buffer and Britton-Robinsion buffer.The height and the shape of the peak were taken into consideration in choosing the suitable supporting electrolyte. Fig. ( 2 ) indicates the dependence of the peak current of $5 \times 10^{-4} \mathrm{~mol} \mathrm{l}^{-1}$ cadmium $\left(\mathrm{Cd}^{++}\right)$on the supporting electrolyte kind using glassy carbon electrode. Fig. (3) indicates the dependence of the peak current of oxidation for $3 \times 10^{-4} \mathrm{~mol}^{1^{-1}}$ cadmium $\left(\mathrm{Cd}^{++}\right)$ on the acetate buffer concentration at $50 \mathrm{mVs}^{-1}$ scane rate using glassy carbon electrode.

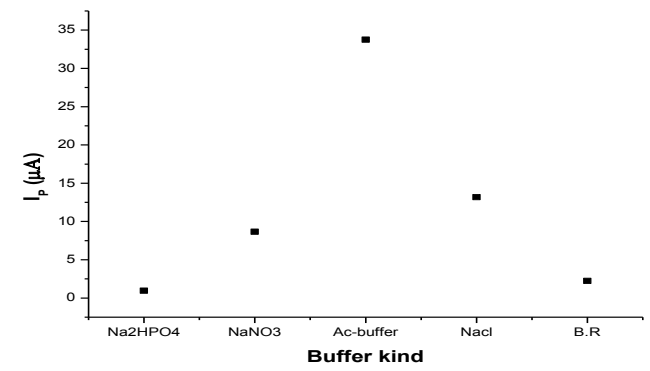

Fig.(2): Dependence of the peak current of $5 \times 10^{-4} \mathrm{~mol} \mathrm{l}^{-1}$ cadmium $\left(\mathrm{Cd}^{++}\right)$on the supporting electrolyte kind using glassy carbon

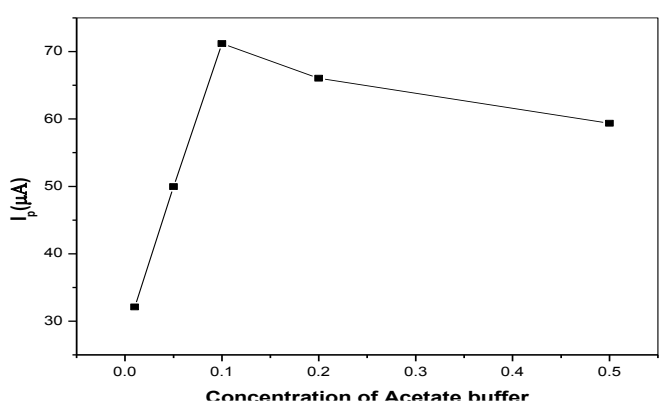

Fig. (3): Dependence of the peak current of $3 \times 10^{-4} \mathrm{~mol} \mathrm{l}^{-1}$ cadmium $\left(\mathrm{Cd}^{++}\right)$on the acetate buffer concentration at $50 \mathrm{mVs}^{-1}$ scane rate using glassy carbon electrode.

\subsection{Influence of $\mathrm{pH}$ of The Supporting Electrolyte :}

The influence of $\mathrm{pH}$ of the supporting electrolyte solution on the peak current of the examined metal ion was studied over the range of ( 2-12). Fig. ( 4 ) shows the Fig. ( 5 ) : Dependence of the peak current of $5 \times 10^{-4} \mathrm{~mol}^{-1}$ lead $\left(\mathrm{Pb}^{++}\right)$on the $\mathrm{pH}$ value of acetate buffer using glassy carbon electrode. The peak potential was shifted to more negative values by increasing the $\mathrm{pH}$ value, as shown in Fig. (5). 


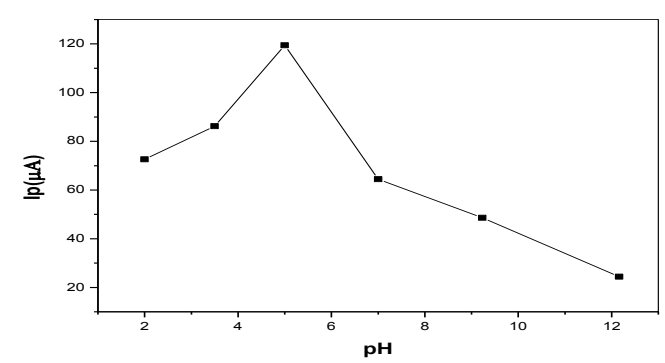

Fig. ( 4 ) : Dependence of the peak current of $5 \times 10^{-4}$ mol $1^{-1}$ lead $\left(\mathrm{Pb}^{++}\right.$ ) on the $\mathrm{pH}$ value of acetate buffer using glassy carbon electrode.

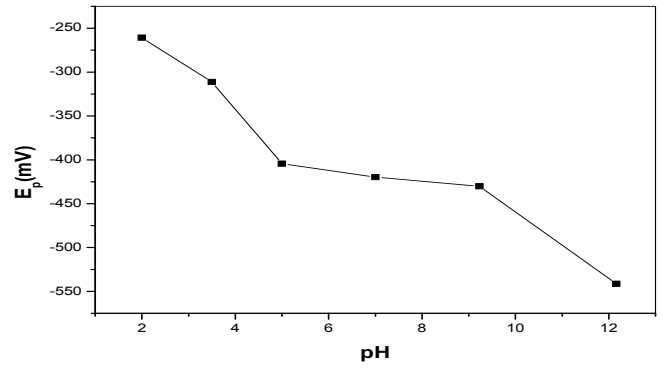

Fig. ( 5 ) : Dependence of the peak potential of $5 \times 10^{-4} \mathrm{~mol} \mathrm{l}^{-1}$ lead $\left(\mathrm{Pb}^{++}\right)$on the $\mathrm{pH}$ value of acetate buffer using glassy carbon electrode

\subsection{Effect of Deposition Potential :}

The effect of deposition potential on the peak current was studied over the range from $0.8 \mathrm{~V}$ to $0.8 \mathrm{~V}$, the recorded peak current showed that the current increases by increasing the accumulation potential to a maximum value at $0.0 \mathrm{~V}$, thereafter the peak current began to decrease Fig. (6). So an accumulation potential of $0.0 \mathrm{~V}$ was used for subsequent work. The accumulation potential has no effect on the peak potential of cadmium $\left(\mathrm{Cd}^{++}\right)$.

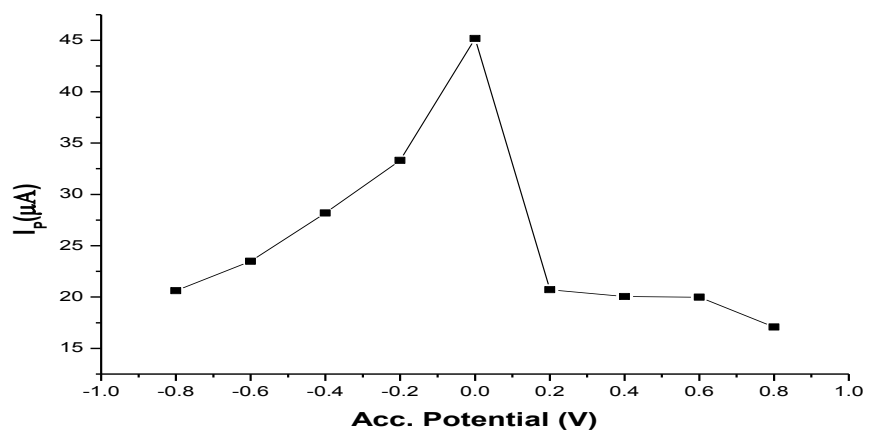

Fig. ( 6 ) : Effect of accumulation potential on the peak current of $8 \times 10^{-5} \mathrm{~mol} \mathrm{l}^{-1}$ cadmium $\left(\mathrm{Cd}^{++}\right)$in $0.1 \mathrm{M}$ acetate buffer $(\mathrm{pH} 5)$ and $50 \mathrm{mVs}^{-1}$ scan rate using glassy carbon electrode.

\section{3..5 Effect of Deposition Time :}

The adsorption behavior of cadmium, copper and lead on glassy carbon electrode has been proved by increasing the peak current with increasing the deposition time. Fig. (7) indicates the voltammograms of $1 \times 10^{-}$ ${ }^{4} \mathrm{~mol} \mathrm{l}^{-1}$ lead $\left(\mathrm{Pb}^{++}\right)$in $0.5 \mathrm{M}$ acetate buffer (pH5), at scan rate of $50 \mathrm{mVs}^{-1}$ using glassy carbon electrode at different deposition times. and

Fig. ( 8 ) represent the effect of deposition time on the peak current of $1 \times 10^{-4}$ mol $1^{-1}$ lead $\left(\mathrm{Pb}^{++}\right)$in $0.5 \mathrm{M}$ acetate buffer ( $\mathrm{pH} 5$ ) and $50 \mathrm{mVs}^{-1}$ scan rate using glassy carbon electrode

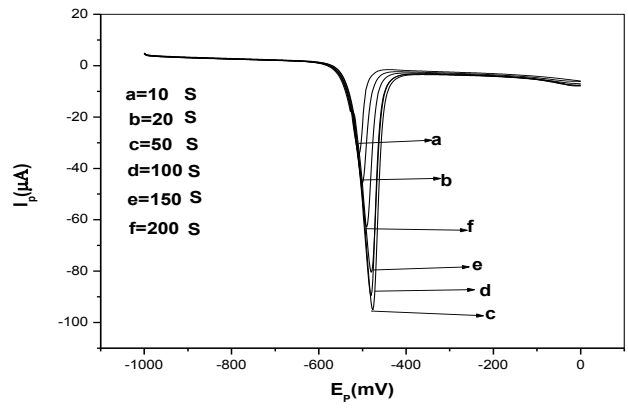

Fig(7): Typical linear voltammogrames of $1 \times 10^{-4} \mathrm{~mol} \mathrm{l}^{-1}$ lead $\left(\mathrm{Pb}^{++}\right)$ in $0.5 \mathrm{M}$ acetate buffer ( $\mathrm{pH} 5)$, at scan rate of $50 \mathrm{mVs}^{-1}$ using glassy carbon electrode at different deposition times.

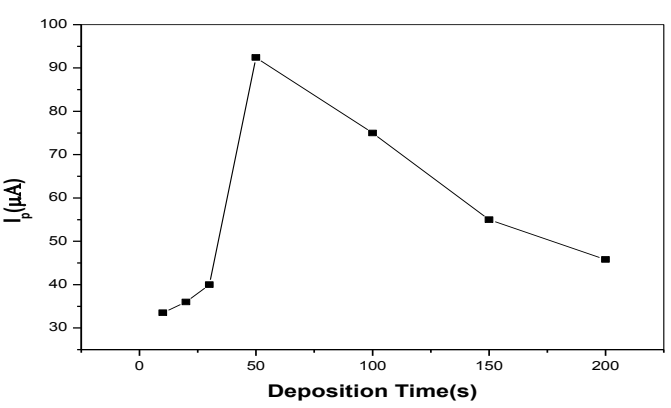

Fig. ( 8 ) : Effect of deposition time on the peak current of $1 \times 10^{-4} \mathrm{~mol} \mathrm{l}^{-1}$ lead $\left(\mathrm{Pb}^{++}\right)$in $0.5 \mathrm{M}$ acetate buffer $(\mathrm{pH} 5)$ and $50 \mathrm{mVs}^{-1}$ scan rate using glassy carbon electrode. 


\subsection{Influence of Scan Rate :}

It was found that the peak current increases by increasing the scan rate, but at scan rate more than 200 $\mathrm{mV} / \mathrm{s}$ the peak shape was distorted. The scan rate of $50 \mathrm{mV} / \mathrm{s}$ was selected for further work to avoid the distortion of the peak at higher concentrations of the metal ion. Fig. (9) shows the voltammograms of $8 \times 10^{-5} \mathrm{M}$ of cadmium $\left(\mathrm{Cd}^{++}\right)$in $0.1 \mathrm{M}$ acetate buffer $(\mathrm{pH} 5)$ at different scan rates. Fig. (10) shows the effect of scan rate on the peak current of $8 \times 10^{-5} \mathrm{M}$ of cadmium $\left(\mathrm{Cd}^{++}\right)$in $0.1 \mathrm{M}$ acetate buffer $(\mathrm{pH} \mathrm{5)}$ at different scan rates, where the peak potential shifted to more positive values by increasing the scan rate Fig. (11) . On plotting Log $\mathrm{I}_{\mathrm{p}}$ (Logarithm peak current) against $\log \mathrm{V}$ (Logarithm of scan rate) for $8 \times 10^{-5} \mathrm{~mol} \mathrm{dm}^{-3}$ cadmium, a linear relation was obtained Fig. (12) with correlation coefficient of 0.99838 . A standard deviation of 0.02447 .

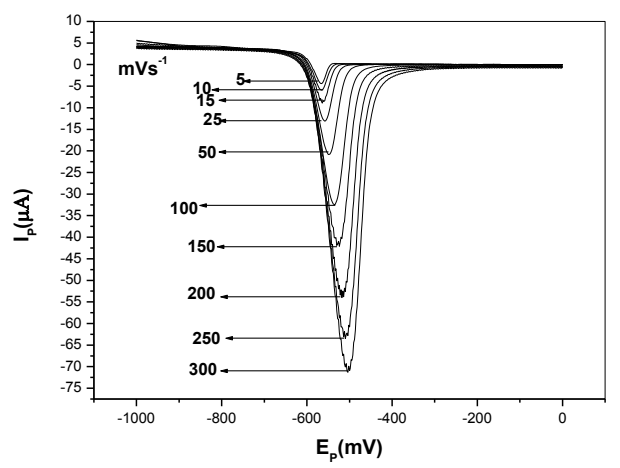

Fig(9): Typical linear Voltammograms of $8 \times 10^{-5} \mathrm{~mol} \mathrm{l}^{-1}$ cadmium $\left(\mathrm{Cd}^{++}\right)$in $0.1 \mathrm{M}$ acetate buffer $(\mathrm{pH} 5)$, at accumulation time 75 $\mathrm{s}$ and different scan rates, using glassy carbon electrode.

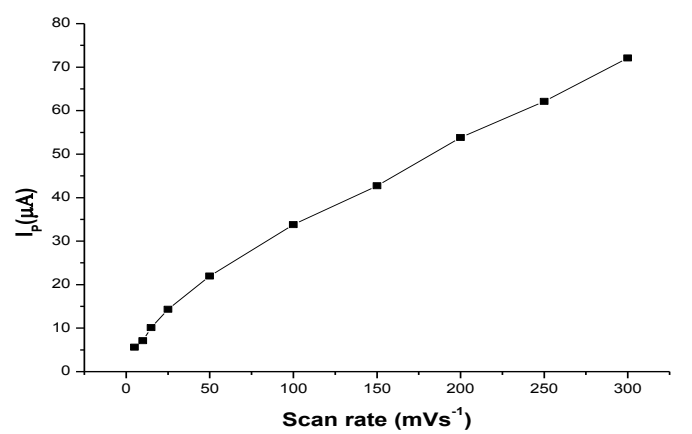

Fig(10): Effect of scan rate on the peak current of $8 \times 10^{-5} \mathrm{~mol} \mathrm{l}^{-1}$ cadmium $\left(\mathrm{cd}^{++}\right)$in $0.1 \mathrm{M}$ acetate buffer $(\mathrm{pH} 5)$, at accumulation time $75 \mathrm{~s}$ using glassv carbon electrode.

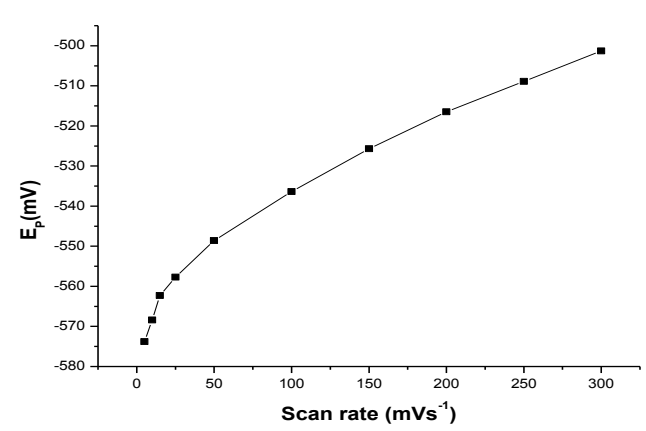

Fig.(11):Effect of scan rate on the peak potential of $8 \times 10^{-5}$ mol $1^{-1}$ Cadmium $\left(\mathrm{Cd}^{++}\right)$in $0.1 \mathrm{M}$ acetate buffer ( $\left.\mathrm{pH} 5\right)$, at accumulation time $75 \mathrm{~s}$ using glassy carbon electrode.

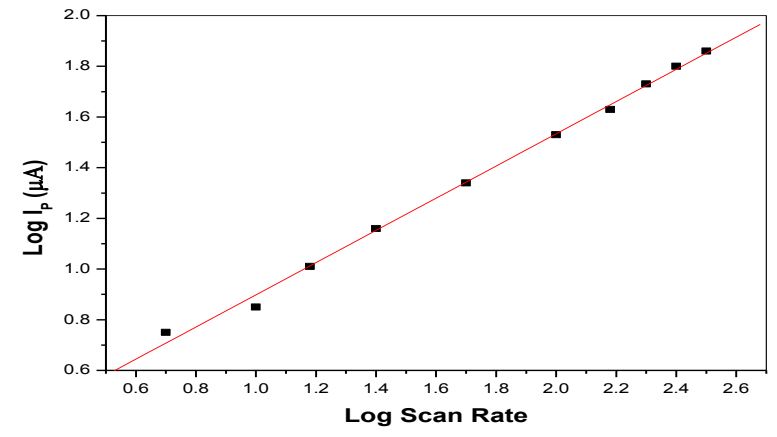

Fig(12): Dependence of logarithm peak current $\left(\log I_{p}\right)$ on logarithm scan rate for $8 \times 10^{-5} \mathrm{~mol}^{-1}$ cadmium $\left(\mathrm{Cd}^{++}\right)$in 0.1 $\mathrm{M}$ acetate buffer( $\mathrm{pH} 5)$ using glassy carbon electrode.

\subsection{Effect of Concentration and Calibration Curve:}

The peak current was increased by increasing concentration of the metal. Fig. (13) shows the voltammogram for different concentrations of cadmium $\left(\mathrm{Cd}^{++}\right), 75 \mathrm{~s}$ deposition time, $0.0 \mathrm{~V}$ accumulation potential and $50 \mathrm{mVs}^{-1}$ scan rate in $0.1 \mathrm{M}$ acetate buffer $(\mathrm{pH} 5)$ using glassy carbon electrode.

On plotting concentration of cadmium $\left(\mathrm{Cd}^{++}\right)$versus the peak current a linear behavior was observed with standard deviation of 0.18428 and correlation coefficient of $0.9993 \mathrm{Fig}(14)$.

The collected data from regression analysis are illustrated in table ( 1 ). The resulted data from the table showed that the linear regression mode is the most suitable one for the relation between the peak current ( Ip ) and the concentration of the tested metal ( C ). 


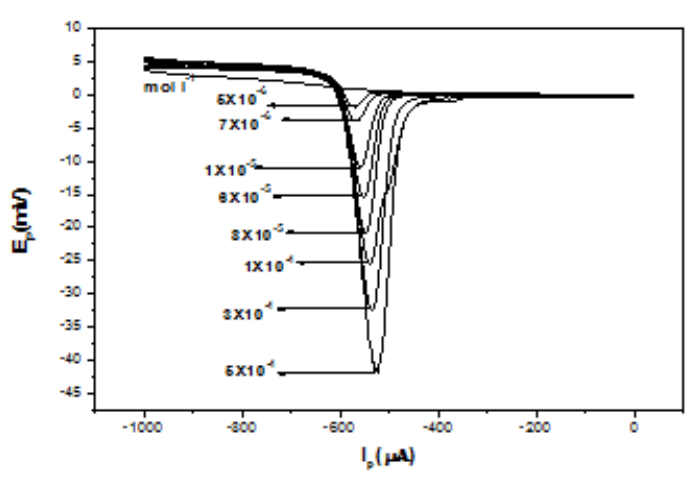

Fig .(13) : Typical linear Voltammograms for different concentrations of cadmium $\left(\mathrm{Cd}^{++}\right)$in $0.1 \mathrm{M}$ acetate buffer $(\mathrm{pH} 5)$, at $50 \mathrm{mVs}^{-1}$ scan rate, $75 \mathrm{~s}$ accumulation time and $0.0 \mathrm{~V}$ accumulation potential using glassy carbon electrode.

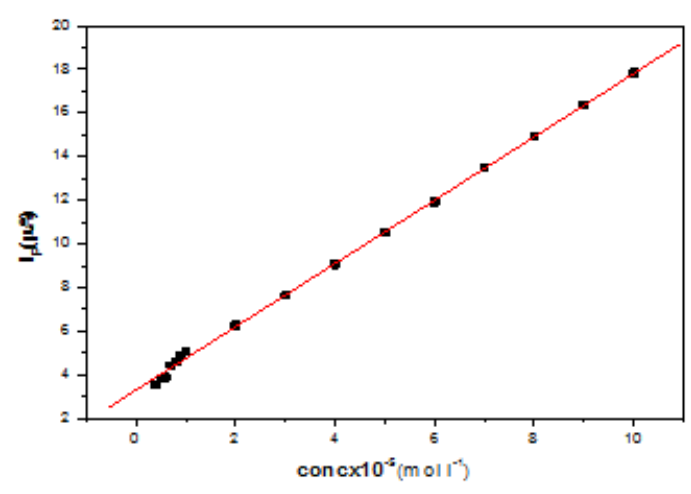

Fig .(14) : Calibration curve of cadmium $\left(\mathrm{Cd}^{++}\right)$in $0.1 \mathrm{M}$ acetate buffer $(\mathrm{pH} \mathrm{5})$, at $50 \mathrm{mVs}^{-1}$ scan rate, $75 \mathrm{~s}$ accumulation time and $0.0 \mathrm{~V}$ accumulation potential using glassy carbon electrode.

\subsection{Quantification Limit :}

Practically using this method a concentration of $3 \times 10^{-6} \mathrm{~mol} \mathrm{dm}^{-3}$ of $\mathrm{Cd}^{2+}$ in acetate buffer $0.1 \mathrm{M}$ $(\mathrm{pH}=5), 75 \mathrm{~s}$ accumulation time, $0.0 \mathrm{~V}$ deposition potential and scan rate of $50 \mathrm{mV} / \mathrm{s}$ by using glassy carbon electrode can be detected.

\subsection{Detection limit:}

Based on $\mathrm{S} / \mathrm{N}=3$ a concentration of $9 \times 10^{-7} \mathrm{~mol} \mathrm{dm}^{-3}, 2 \times 10^{-7} \mathrm{~mol} \mathrm{dm}^{-3}$ and $2 \times 10^{-7} \mathrm{~mol} \mathrm{dm}^{-3}$ of $\mathrm{Cd}^{2+}$, $\mathrm{Pb}^{2+}$ and $\mathrm{Cu}^{2+}$ can be detected.

\subsection{Effect of Interference :}

The interference problems in stripping analysis include the formation of intermetallic compounds, adsorption of organic substances on the electrode and overlapping peaks. So the effect of some metal ions, Lascorbic acid, D-glucose and some amino acids on the peak current of cadmium, copper and lead was studied.

Table 2. indicates the effect of $5 \times 10^{-5} \mathrm{~mol} \mathrm{dm}^{-3}$ of some different interferents on the peak current of $5 \times 10^{-5} \mathrm{~mol} \mathrm{dm}^{-3}$ of cadmium, copper and lead

Table 2. Effect of different interfernces on the peak current of the studied metal ions. .

\begin{tabular}{|c|c|c|c|}
\hline Interferent & $\mathrm{Pb}^{++}$ & $\mathrm{Cu}^{++}$ & $\mathrm{Cd}++$ \\
\hline L-leucine & No significant effect & $-8 \%$ & $-7.82 \%$ \\
\hline D-glucose & $-14.5 \%$ & $-6.86 \%$ & $-17.8 \%$ \\
\hline L-ascorbic acid & $-16 \%$ & $-6 \%$ & $-10.48 \%$ \\
\hline Hydroquinone & $-14.58 \%$ & $-16 \%$ & $+18.88 \%$ \\
\hline Mono chloro acetic acid & $-9 \%$ & $-13.42 \%$ & $+31.69 \%$ \\
\hline p-nitro benzoic acid & +30.4 & $-19.45 \%$ & $-22.1 \%$ \\
\hline p-nitro benzaldahyde & $-9.8 \%$ & $-18.33 \%$ & $-20.45 \%$ \\
\hline
\end{tabular}

Experimental details 2

$\mathrm{CH} 3 \mathrm{COOH}$ and $\mathrm{CH} 3 \mathrm{COONa}$ were used for the preparation of a 0.1 and $0.5 \mathrm{M}$

acetate buffer solution in the case of cadmium and lead respectively while in the case of copper a stock Britton-Robinson buffer solution of $0.1 \mathrm{M}$ with respect to boric, orthophosphoric and acetic acids was prepared from analytical grade reagents. Stock solutions of $\mathrm{Pb}(\mathrm{CH} 3 \mathrm{COO}) 2.3 \mathrm{H} 2 \mathrm{O}, \mathrm{CdCl} 2.2 \mathrm{H} 2 \mathrm{O}$ and $\mathrm{CuCl} 2.5 \mathrm{H} 2 \mathrm{O}$ (Sigma-Aldrich) were diluted using doubly distilled water to a concentration of $1 \mathrm{mM}$ each and stored at room temperature. All the chemicals used were of analytical reagent grade. All electrochemical experiments such as voltammetric measurements were performed using A computer-aided electrochemistry :system. The system consists of the following

A potentiostat model 263 (EG\& G PARC) Princeton applied corporation -
of modern stripping analyzer potentiostat control of working electrode, which

The characteristic of modern stripping analyzer potentiostat control of working electrode, which
minimize errors from the cell resistance (distorted voltammogram with decreased peak current and shifted and broadened peaks)(9). This is accomplished with a three-electrode system, a GCE of a diameter of $3 \mathrm{~mm}$ as the working electrode, a platinum mesh as the counter electrode and an $\mathrm{Ag} / \mathrm{AgCl}$ (saturated $\mathrm{KCl}$ ) reference electrode(10). These electrodes, as well as a tube used for bubbling the inert (nitrogen) gas to deairate the .solution, are supported in four holes in the cover; a fifth hole in the cover is used for standard addition Thoroughly polished GCE surfaces using a slurry containing $0.3 \mu \mathrm{m} \alpha-\mathrm{Al} 2 \mathrm{O} 3$ powders on a soft cloth . were sonicated in first ethanol and then doubly distilled water for $3 \mathrm{~min}$ each to remove possible 
contaminants(11). For the study of sensing trace heavy metals in aqueous solutions using the electrodes in this study, the electrodes were dipped in a 0.1 and $0.5 \mathrm{M}$ acetate buffer solution $(\mathrm{pH} 5)$ and $0.1 \mathrm{M}$ Britton-Robinson buffer solution $(\mathrm{pH} 2)$ containing predetermined concentrations of $\mathrm{Cd} 2+$ and $\mathrm{Pb} 2+$ and $\mathrm{Cu} 2+$ ions respectively .that were the target metals to be investigated

\section{References}

[1] W. Franklin Smyth "Polarography of Biological Significance" (1979).

[2] Bull. Korean, 2002, Chem. Soc. Vol. 23, No. 81169.

[3] Babaei, Babazadeh, \& Shams, Electroanalysis 19 (2007) 1215-1219.

[4] Guanghan et al., 2004. Food Chemistry 84 (2004) 319-322.

[5] Gholivand, Sohrabi, \& Abbasi, 2007, Food Chemistry, 116, 1019-1023.

[6] Adinarayan Reddy, Janardhan Reddy, Lakshmi Narayan, \& Varada Reddy, Food Chemistry 109 (2008) 654-659.

[7] J.K. Dunnick, B.A. Fowler, Cadmium, in: H.G. Seiler, H. Sigel (Eds.), Handbook on Toxicity of Inorganic Compounds (Chapter 14), Marcel Dekker, New York, 1988.

[8] R.T. Daher, Anal. Chem. 67(12) (1995) 405R.

[9] L. Chen, Z. Su, X.He, Y. Liu, C. Qin, Y. Zhou, Z. Li, L. Wang, Q. Xie, S. Yao, Electrochemistry Communications 15 (2012) 3437.

[10] Z. Wang, E. Liu, X. Zhao, Thin Solid Films 519 (2011) 5285-5289.

[11] K. Shi, K. K. Shiu, Electrochimica Acta 51 (2006) 2631-2638. 